\title{
Aristotle and the Virtues of Will Power ${ }^{1}$
}

\author{
Noell Birondo \\ Wichita State University
}

1. Since the 1970s, at least, and presumably under the influence of the later Wittgenstein, certain advocates of Aristotle's ethics have insisted that a proper validation of the virtues of character must proceed only from within, or be internal to, the particular evaluative outlook provided by possession of the virtues themselves. The most influential advocate of this line of thinking is arguably John McDowell, although Rosalind Hursthouse and Daniel C. Russell have also more recently embraced it. ${ }^{2}$ Here I consider whether a distinction between the 'substantive virtues' and the 'virtues of will power' ultimately threatens that way of thinking about Aristotle's ethics. If so, it would encourage a different reading of Aristotle's ethics, one that McDowell has described as a "historical monstrosity" (1994, p. 79; 1998b, p. 195).

Consider first what this different, 'external' validation of the virtues would amount to. An external validation of the virtues of character is an attempt to demonstrate that possession of the virtues is necessary in order to secure some good, or to avoid some harm, where the good in question, or the harm, is recognizable as such independently of the particular evaluative outlook provided by possession of the virtues themselves. The validation will thus rely on resources that are 'external' to the particular evaluative outlook to be validated. By contrast, an internal validation of the virtues would be one according to which the good unattainable without the virtues, or the harm unavoidable without them, are only recognizable as such from within the evaluative outlook provided by possession the virtues. ${ }^{3}$ They are not recognizable as such by anyone, simply in virtue of possessing human recognitional capacities; and they could not therefore provide the materials out of which a philosopher might hope to straightarm someone - straight-arm anyone - into living as morality requires. This last thought should call to mind what Bernard Williams (1985) considered to be the philosophically misguided aim of trying to provide an 'Archimedean Point' in ethics. But Williams apparently saw Aristotle as someone trying to provide a philosophical foundation for the ethical life: something that could serve as a justification, for anyone, of that type of life. Only an external validation of the virtues could accomplish something like that. Indeed, according to McDowell, both Williams (1985) and Alasdair MacIntyre (1981) think that Aristotle aimed to validate his 
own particular list of the virtues by appealing to a (no longer believable) teleological conception of nature (McDowell, 1994, p. 79). The teleological conception of nature was supposed to dictate what man's 'function' is. And it was therefore also able to dictate what the distinctively human virtues are, given the conceptual connections that Aristotle exploits (in Nicomachean Ethics I.7) between 'function,' 'activity,' and 'virtue.' The teleological conception of nature would therefore furnish an external validation of the virtues in the relevant sense. On this view of what Aristotle is up to, recognizing what functioning well is for human beings - recognizing what the good for man is - is not something that requires a properly formed evaluative outlook. The good for man can be recognized as such by anyone who understands the teleological conception of nature that, on this reading of Aristotle, underwrites it.

As we have seen, McDowell finds the interpretation repulsive: it is specifically in reference to Williams and MacIntyre that McDowell characterizes the interpretation as a historical monstrosity. What is crucial here, however, is certainly not McDowell's polemics, but rather the fact that an external validation of the virtues might proceed by specifying some good as the distinctively human good: something that is both recognizable as such independently of a properly formed evaluative outlook and also clearly unattainable without the virtues. ${ }^{4}$

2. That is not, however, the only way to provide an external validation of the virtues. The guiding notion of a different external validation would be, not that there is some good that is unattainable without the virtues, but rather that there is some harm that is unavoidable without the virtues. In order for such a validation to be persuasive, one would have to argue that possession of the virtues reliably allows one to avoid the harm in question; and in order for it to be an external validation, one would have to specify the harm in such a way that it was recognizable as such independently of the evaluative outlook provided by possession of the virtues. This would presumably establish that certain character traits are distinctively human excellences because they are in a crucial sense indispensable: they serve as correctives. ${ }^{5}$

On this approach to an external validation of the virtues, everything turns on specifying the harm to be avoided. An ethically loaded specification of the harm to be avoided can, on the one hand, certainly seem useless. We can of course maintain that the harm to be avoided by possession of the virtues is 'cowardice,' say, or 'intemperance.' But that characterization trivializes the thought that the virtues are correctives. After all, no characterization of the Aristotelian virtues is adequate unless it specifies that 
possession of the virtues allows one to avoid vice; but the specification by itself lacks philosophical substance, and it therefore leaves the claim that the virtues are a kind of human excellence unexplained. Cowardice and intemperance are, in any case, recognizable as harms to be avoided (in the ethically loaded sense) only from within the evaluative outlook provided by possession of the virtues. But we are considering the prospects for an external validation of the virtues, based on the thought that the virtues serve as correctives.

The harm to be avoided can, on the other hand, be characterized independently of specifically ethical language. We can say that the virtues are human excellences because they allow us to avoid the harms of flight in battle, say, or of drinking ourselves into drunkenness. But why, one might ask, should these activities be taken to constitute a kind of harm? Why is the notion of correction supposed to be at home here? We could, certainly, consider such activities harmful if we possessed a criterion of right conduct that did not already presuppose that the virtues are human excellences; but presumably the project of an ethics of virtue is to specify the excellence of the virtues independently of any antecedent criterion of right conduct (see Watson, 1990 and Kawall, 2009). ${ }^{6}$ What these considerations so far suggest is that an external validation of the virtues, based on a characterization of the virtues as correctives, is quite unlikely to succeed.

3. Perhaps it will be objected, however, that this negative conclusion about the prospects for an external validation of the virtues can be reached only by failing to acknowledge a unique role played in an ethics of virtue by the 'virtues of will power.' Such a role has been given special emphasis by Robert C. Roberts in his insightful (1984) paper "Will Power and the Virtues." In this paper Roberts distinguishes between what he calls the 'substantive' (or 'motivating') virtues, and what he calls the 'virtues of will power.' The substantive virtues are virtues such as honesty, compassion, justice, generosity, promise-keeping, and kindness - virtues that are, according to Roberts, psychological embodiments of ethical rules. Genuine possession of the substantive virtues ensures that the conduct of their possessors will be (barring weakness of will) moral conduct. As opposed to this, however, the so-called virtues of will power do not, according to Roberts, imply "any characteristically ethical patterns of behavior, judgment, or emotion" (1984, p. 229). Roberts's examples of the virtues of will power are courage, patience, self-control, and perseverance - character traits, that is, whose possession is apparently consistent with even the most reviled types of behavior. The virtues of will power do not therefore ensure that their possessors' conduct will be in the least bit moral; it is 
rather that for someone who already possesses the substantive virtues, the virtues of will power are what ensure that, in the face of certain countermoral temptations, their possessors will not stray from what Roberts calls the path of virtue.

How does Roberts's account affect the thesis that the excellence of the virtues does not reside in their being corrective? Roberts explicitly considers this suggestion - which he finds, at least, in the work of Philippa Foot - and he argues that the proposal carries real philosophical significance only in the case of the virtues of will power. As far as the substantive virtues are concerned, Roberts agrees that such character traits are corrective only in the trivial sense that I mentioned: possession of these virtues precludes (and so in a trivial way 'corrects' for) possession of the corresponding vices. In the case of the virtues of will power, however, Roberts claims that things are quite different. The virtues of will power are corrective, he says, in the significant sense that they keep us "on the path of virtue and our highest self-interest" (1984, p. 233), especially in the face of our all-too-human moral frailty. This point is emphasized when Roberts considers the possibility of those who may possess the substantive virtues to such a degree that certain counter-moral temptations no longer afflict them. Such moral saints, as Roberts calls them, have attained a level of moral purity that makes the virtues of will power, in them, unnecessary. Thus Roberts writes that the virtues of will power "are not the substance of the moral life and their 'corrective' function is no longer needed when full sainthood has been attained" (1984, p. 234). In order to highlight the connection that, on this account, ties the virtues of will power to their special corrective function, Roberts writes that in such moral saints, "courage is not a function of will power" (1984, p. 237). On Roberts's account, then, the virtues of will power attain their status as virtues from the role they play in the lives of those who possess the substantive virtues, but who are still, in spite of this fact, liable to be assaulted by the temptations for which the virtues of will power are meant to correct. The excellence of the virtues of will power, that is, resides in their correcting for the harmful effects of counter-moral impulses or temptations: something that we can recognize as harmful precisely because the status of the substantive virtues as virtues is not here in question.

4. Nevertheless, Roberts's analysis of the virtues of will power does not in fact threaten my negative assessment about the prospects for an external validation of the virtues. For his analysis does not establish that the excellence of the virtues of will power resides in their being corrective. It fails to do so even if we admit, as we should, that appealing to the substantive 


\section{Aristotle and the Virtues of Will Power}

virtues allows one to pinpoint a definite sense in which succumbing to counter-moral impulses does indeed constitute a kind of harm. As Roberts himself is more than ready to admit, the virtues of will power are not corrective in the case of people whose moral progress is so advanced that it makes them immune to certain kinds of temptation. But surely the virtue of courage (say) does not in fact forfeit its status as a virtue in people such as these. One might even be willing to say, with Aristotle, that someone who truly possesses the virtue of courage will not - precisely because she is courageous - be susceptible to the temptations which assault people in the face of danger. It is not that courage is needed in order to correct for an impulse to retreat in the face of danger, but rather that in people who exhibit the virtue of courage, such impulses do not arise. Now Roberts $(1984$, n. 2) does indeed say that not every action exemplifying one of the virtues of will power is in fact an exercise of will power. This means that being an exercise of will power is not a necessary feature of the virtues of will power. But given Roberts's emphasis on the corrective function of these virtues, it is difficult to imagine how they can retain their status as virtues in the lives of those who are not afflicted by the corresponding temptations. ${ }^{8}$ What this ultimately shows, I think, is that the path-guiding function can only trivially be characterized as a corrective function. Appealing to such a function cannot help furnish an external validation of the virtues of will power.

Roberts does acknowledge that, on the issue of temptation, his account departs significantly from Aristotle. He takes explicit issue, for instance, with Aristotle's claim that the man who "abstains from bodily pleasures and enjoys doing so is self-controlled" (Nicomachean Ethics 1104b5-7; quoted in this translation by Roberts, 1984, p. 230). As opposed to this, Roberts says that enjoying such activity is not a criterion of self-control, no doubt because Roberts sees 'self-control' - Aristotle's own word is sôphrosunê, most often translated as "temperance" - as a striving to resist temptation (1984, pp. 230-31). But while Aristotle would readily acknowledge that striving against bodily temptation is difficult, and certainly displeasing, he does not think that anyone for whom such striving is necessary is someone who possesses the virtue of temperance. For even the person who successfully overcomes such temptations displays at best what Aristotle calls continence - what we might call mere self-control - something that Aristotle rightly says is not a manifestation of genuine virtue. (In opposition to Aristotle's recommendation, that ethical agents aspire to more than continence, Roberts recommends "exercises by which a person can increase his ability to resist temptation" (1984, p. 244), citing E. J. Boyd Barrett's 1915 book, Strength of Will and How to Develop It, the 
quality of whose advice is suggested by the title of Barrett's slightly later 1917 book, The Will to Win: A Call to American Boys and Girls. ${ }^{9}$ ) But even if Roberts were right that self-control, as opposed to temperance, is a genuine virtue, I think it goes not only against Aristotle, but also against what seems true in any case, to claim that the 'virtues of will power' forfeit their status as virtues in the lives of those who are unafflicted by certain kinds of temptation. My negative assessment about the prospects for an external validation of the virtues does not therefore seem to be threatened by distinguishing, as Roberts's does, between the substantive virtues and the virtues of will power.

There is, however, still another reason for thinking that my negative assessment emerges intact. This is the fact that the corrective function of the virtues of will power, in those of us who are not moral saints, can only be made intelligible by appeal to whatever excellence or goodness has already been attributed to the substantive virtues. It is perhaps worth mentioning that Roberts seems not to notice this. In discussing the courage of a thief, Roberts remarks that "though his disregard for property rights is despicable, still he possesses a trait without which one leads a crippled life" (Roberts, 1984, p. 231). But it is unclear what notion of defect, or handicap, is supposed to be at work here, since courage will obviously not preclude the thief from wandering off the path of virtue: that isn't the path he is traveling. ${ }^{10}$ Nevertheless, on Roberts's account, the virtues of will power attain their status as virtues precisely because they correct for temptations to stray from the path determined by the substantive virtues; and straying from the path of virtue is for that reason taken, perfectly intelligibly, to constitute a kind of harm. But since this validation of the virtues of will power takes for granted the excellence of the substantive virtues, it does not appeal to anything external to what, from the point of view of Aristotle's ethics, is a properly formed evaluative outlook. Providing a successful external validation of the virtues, by enlisting the distinction pressed by Roberts, therefore seems to me to be quite unlikely.

5. Given this conclusion, it is perhaps worth turning briefly to the question of how this external approach for validating the virtues of character has managed to become so influential. One source of influence is almost certainly a discomfort that contemporary ethical theorists feel with Aristotle's own, apparently self-contained conception of the virtues. The contemporary philosophical climate seems to demand a justification in ethics that can be constructed solely from materials which lie outside of the ethical life. And yet there is at least one other source of the desire to provide an external validation of the virtues. This is the suspicion that the only avail- 


\section{Aristotle and the Virtues of Will Power}

able alternative to an external validation, proceeding only from within the evaluative outlook provided by the virtues, could never really amount to a genuine validation of the virtues. One will perhaps be reminded, in what is admittedly a rather different context, of a picture that Wilfred Sellars (1956, §38, p. 300) warned against in our attempts to provide an account of empirical knowledge: the picture of a great Hegelian serpent with its tail in its mouth. ${ }^{11}$ If accepting that Hegelian picture is the only available alternative to an external validation of the virtues, then we should not wonder that such prominent ethical theorists have tried to develop an ethics of virtue along lines that move in the opposite direction. Whether an internal validation of the virtues of character can ultimately succeed is, as it seems to me, both a genuine and a genuinely troubling question for anyone concerned to defend an Aristotelian ethics of virtue. And while I need not, for my purposes here, address the prospects for a successful internal validation of the virtues, I do think that addressing that question, and addressing the prospects for a satisfying Aristotelian ethical theory, amount to very much the same thing. ${ }^{12}$ In my view, this is why John McDowell's views on this issue have been so widely influential, and also why more recent attempts to articulate an internal validation of the virtues remain well worth our philosophical attention. ${ }^{13}$

\section{Notes}

1 This article was supposed to appear in SPR 31(1), the January 2015 issue. But, due to errors in the layout process, the version which appears there is incomplete, missing three important paragraphs. To correct the mistake, the editor, Todd Stewart, has decided to reprint the article in full in this issue. All scholarly citations should be to the version as it appears here.

2 See the papers on Aristotle's ethics collected in McDowell (1998a; 1998b); Hursthouse (1999, especially chs. 8-11); and Russell (2009, especially Part I).

3 The evaluative outlook in question need not be provided only by possession of the virtues, since it can also be shared by people who, like most of us, never manage to proceed further than Aristotelian continence.

4 For interpretations of Aristotle's 'function' argument that contrast with the external reading, see McDowell (1980); Broadie (1993, ch. 1), and Nussbaum (1995). Julia Annas (1988) considers more generally the appeal to human nature in Greek ethics, in her strangely neglected article "Naturalism in Greek Ethics: Aristotle and After."

5 This corrective thesis has been defended explicitly in Von Wright (1963) and Foot (1978). There is something similar in MacIntyre's reading of Aristotle (1981) and in MacIntyre's own later defense of the virtues (1999). According to this later account, human beings need the virtues because we are dependent ratio- 


\section{Noell Birondo}

nal animals, because we are in various ways crippled.

6 For her own reasons, Paula Gottlieb also objects to this corrective thesis: see Gottlieb (2009, ch. 3).

7 More recently Robert Adams (2006) has deployed the same distinction, with specific reference to Roberts's paper, in order to articulate his own account of the virtues; hence the philosophical significance of the distinction remains an open question. In this paper I mean to emphasize something that I think the distinction cannot help one accomplish.

8 It cannot be because the virtues of will power are psychologically necessary in order to develop the substantive virtues, since moral saints already have those: see Roberts (1984, pp. 233-36).

9 Mark Alfano has recently suggested some rather more plausible, empirically sanctioned methods for stimulating moral improvement, methods that are not themselves (unlike his conception of philosophical situationism) inhospitable to Aristotelian virtue ethics: see Alfano (2013, ch. 4). Contrast Alfano's suggestions with Barrett's invocation, "To write out, with great care, twenty times 'I will train my Will."”

10 Perhaps the mastery of fear retains its excellence here because such mastery would be a virtue in someone with less deplorable ends, and because the ability to master one's fear is a distinctively human excellence, the thief (murderer, Nazi, etc.) remaining, whatever else she is, a human being. (The suggestions are from Robert Roberts: see note 13 below.) This line seems rather more difficult to take, though, in praising the perseverance of Jerry Sandusky in the Penn State child rape scandal: for instance as directed at his victims.

11 Jonathan Lear's apt observation that "one man's internal validation is another man's begging the question" is also very much to the point here: see Lear (1995). On the other hand, I do not myself see why, as Jesse Prinz (2009, p. 136) has baldly claimed, the assessment of some alternative conception of 'wellbeing,' made from within (or better: from) our own evaluative framework, must "inevitably impose our own conception of well-being on others."

12 The prospects will hinge, for instance, on providing a normatively adequate standard of ethical consistency while "rejecting the claim that normative adequacy requires nominal consistency" (Russell, 2009, p. 294). My discussion of Roberts's account above can perhaps contribute, in a modest way, to thinking through the many difficult issues surrounding the normative adequacy of an 'internal' conception of the virtues.

13 Earlier versions of this paper were presented at the annual meetings of the American Philosophical Association (Pacific, 2008) and the Southwestern Philosophical Society (2014). Thanks are due to the participants on each of these occasions, and especially to Robert Roberts, for his helpful commentary at the APA. Special thanks are due to Minh T. Nguyen, for encouraging me to consider Roberts's discussion of these issues, and to Lillian Dickerson, for indispensable editorial assistance. 


\section{Aristotle and the Virtues of Will Power}

\section{Works Cited}

Adams, Robert Merrihew. (2006) A Theory of Virtue: Excellence in Being for the Good. Oxford: Oxford University Press.

Alfano, Mark. (2013) Character as Moral Fiction. Cambridge: Cambridge University Press.

Annas, Julia. (1988) Naturalism in Greek Ethics: Aristotle and After. Proceedings of the Boston Area Colloquium in Ancient Philosophy 4: 149-171.

Broadie, Sarah. (1993) Ethics with Aristotle. Oxford: Oxford University Press.

Foot, Philippa. (1978) Virtues and Vices. In her Virtues and Vices and Other Essays in Moral Philosophy (pp. 1-18). Berkeley: University of California Press.

Gottlieb, Paula. (2009) The Virtue of Aristotle's Ethics. Cambridge: Cambridge University Press.

Hursthouse, Rosalind. (1999) On Virtue Ethics. Oxford: Oxford University Press.

Kawall, Jason. (2009) In Defense of the Primacy of the Virtues. Journal of Ethics \& Social Policy 3: 1-21.

Lear, Jonathan. (1995) Testing the Limits: The Place of Tragedy in Aristotle's Ethics. In Robert Heinaman (ed.), Aristotle and Moral Realism (pp. 61-84). Boulder: Westview Press.

MacIntyre, Alasdair. (1981) After Virtue: A Study in Moral Theory. Notre Dame: University of Notre Dame Press.

—. (1999) Dependent Rational Animals: Why Human Beings Need the Virtues. LaSalle: Open Court.

McDowell, John. (1980) The Role of Eudaimonia in Aristotle's Ethics. In Amélie Oksenberg Rorty (ed.), Essays on Aristotle's Ethics (pp. 359-376). Berkeley: University of California Press.

- (1994) Mind and World. Cambridge: Harvard University Press

(1998a) Mind, Value, and Reality. Cambridge: Harvard University Press.

- (1998b) Two Sorts of Naturalism. In his Mind, Value, and Reality (pp. 167-197).

Nussbaum, Martha. (1995) Aristotle on Human Nature and the Foundations of Ethics. In J. E. J. Altham and Ross Harrison (eds.), World, Mind and Ethics: Essays on the Ethical Philosophy of Bernard Williams (pp. 86-131). Cambridge: Cambridge University Press.

Prinz, Jesse. (2009) The Normativity Challenge: Cultural Psychology Provides the Real Threat to Virtue Ethics. Journal of Ethics 13: 117-144.

Roberts, Robert C. (1984) Will Power and the Virtues. Philosophical Review 93: 227-247.

Russell, Daniel C. (2009) Practical Intelligence and the Virtues. Oxford: Oxford University Press. 


\section{Noell Birondo}

Sellars, Wilfred. (1956) Empiricism and the Philosophy of Mind. In Herbert Feigl and Michael Scriven (eds.), Minnesota Studies in the Philosophy of Science, Vol. I (pp. 253-329). Minneapolis: University of Minnesota Press.

Von Wright, G. H. (1963) The Varieties of Goodness. London: Routledge \& Kegan Paul.

Watson, Gary. (1990) On the Primacy of Character. In Owen Flanagan and Amélie Oksenberg Rorty (eds.), Identity, Character, and Morality: Essays in Moral Psychology (pp. 49-69). Cambridge: MIT Press.

Williams, Bernard. (1985) Ethics and the Limits of Philosophy. Cambridge: Harvard University Press. 